\title{
A Reason of Delayed Weaning in Critical Care: Amiodarone Pulmonary Toxicity
}

\author{
Yoğun Bakımda Gecikmiș Weaning Nedeni Olarak Amiodaron Pulmoner Toksisitesi
}

\author{
Mesut Öterkuș', Aysu Hayriye Tezcan', İlksen Dönmez', Sunay Sibel Karayol' , Ömür Öztürk \\ ${ }^{1}$ Kafkas University Faculty of Medicine, Department of Anesthesiology and Reanimation; ${ }^{2}$ Department of Radiology, Kars; \\ ${ }^{3}$ Canakkale 18 Mart University Faculty of Medicine, Department of Anesthesiology and Reanimation, Çanakkale, Turkey
}

\begin{abstract}
Amiodarone is a frequently used antiarrhythmic drug in critical care which was used to treat especially ventricular arrhythmias. But it must known that secondary to its chemical properties, drug tends to accumulate in tissues and it presents as cardiac, ophtalmic, pulmonary and neurological side effects. Amiodarone pulmonary toxicity (APT) is one of the life-threatening side effects of the drug which may present as respiratory failure. And thorax computed tomography scans demonstrate the pathology with pneumonitis, groung glass opacities and fibrosis. Dispnea and cough are common clinical presentations. But an intubated and mechanically ventilated patient's respiratory failure secondary to APT may reflect as only delayed weaning as in our case. Most importantly, rapid diagnosis and early treatment are the most important factors that reduce the mortality of patients.
\end{abstract}

Key words: amiodarone; pulmonary toxicity; critical care

\section{ÖZET}

Amiodaron yoğun bakımda sıkça kullanılan bir antiaritmiktir ve özellikle ventriküler aritmilerin tedavisinde kullanılır. Ama bilinmelidir $k i$ kimyasal yapısından dolayı ilaç dokularda birikebilir ve kardiyak, oftalmik, pulmoner ve nörolojik yan etkiler olușturabilir. Amiodaron pulmoner toksisitesi (APT) ilacın hayatı tehtit eden yan etkilerinden biridir ve solunum yetmezliği șeklinde karșımıza çıkabilir. Hastalık toraks bilgisayarlı tomografisinde pnömonitis, buzlu cam opasiteleri, fibrosis bulgularını verir. Dispne ve öksürük en sık görülen belirtilerdir. Ancak tıpkı bizim olgumuzda olduğu gibi, entübe ve mekanik ventilasyon uygulanan bir hastada APT'nin yarattığı solunum yetmezliği karșımıza sadece gecikmiș ventilatörden ayrılma olarak çıkabilir. En önemlisi hızı tanı ve erken bașlanan tedavi hastaların mortalitesini azaltan en önemli faktörlerdir.

Anahtar kelimeler: amiodaron; pulmoner toksisite; yoğun bakım

Aysu Hayriye Tezcan, Kafkas Üniversitesi Tip Fakültesi, Sağllk Uygulama Araștrrma Hastanesi, Kars, Türkiye,Tel.05326735711Email.aysndr@gmail.com Geliş Taribi: 09.01.2017 • Kabul Taribi: 22.02.2017

\section{Introduction}

Amiodarone is one of the most prescribed antiarrhthmic drug by clinicians. The popularity of the drug comes from its efficacy and extend indications in terms of different types of arrhythmias. But amiodarone has relations with dangerous side effects like amiodarone pulmonary toxicity (APT). The prevalence is estimated to be about $5 \%$. The risk of APT occurance increased by drug dose and therapy duration. Clinical manifestations of APT are; decreased lung capacity, cough, weight loss ${ }^{1,2}$. But in critical care these manifestations may be masked and clinician must be aware of APT, whether the patient used high dose of amiodarone. In this case report we present a delayed weaning according to APT with it's clinical presentation, diagnosis and successful therapy.

\section{Case}

65-year-old female patient with hypertension, diabetes and chronic obstructive pulmonary disease, obesity $\left(\mathrm{BMI}>35 \mathrm{~kg} / \mathrm{m}^{2}\right)$ referred to the hospital with respiratory failure. Acute coronary syndrome was detected and percutan coronary angiography was performed. During the procedure two clogged coronary arteries opened successfully. Secondary to unstable haemodynamic measurements patient transferred to our critical care service. After the physical and laboratry examination, atrial fibrillation, significant respiratory failure secondary to pulmonary edema and pneumonia, impaired renal functions secondary to contrast induced nephropathy were detected additionally to the acute coronary syndrome. Patients glasgow coma scale was 14 at the application to the critical care. Secondary to respiratory failure supportive noninvasive mechanical ventilation started. Hemodialysis was performed for deep metabolic acidosis secondary 
to renal impairment. Antibiotic therapy for pneumonia and other recommended drugs (acetylsalicilic acid $1 \times 100 \mathrm{mg} /$ day, clopidogrel $1 \times 75 \mathrm{mg} /$ day, metoprolol $1 \times 50 \mathrm{mg} /$ day) by cardiologists were started. At the 4th day of the critical care cardiac arrest occurred secondary to malignant ventricular arrhthmias. Three times cardioversion was performed with successful resuscitation. Patient started to receive per oral amiodarone $(2 \times 200$ $\mathrm{mg} /$ day) therapy. At the 7 th day of the critical care malignant arrhythmais reappeared and cardioversion was performed again. The amiodarone dose concluded insufficient and it increased to $3 \times 200 \mathrm{mg} /$ per day. From the fourth day of the process patients was still intubated and mechanically ventilated. Hemodialysis therapy was still continue every two days. Cardiac rithm of the patient stabilized. After a few days pneumonia was deteriorated, volume load on lungs depleted and weaning planned. Intermittent chest $\mathrm{x}$-rays showed new patchy infiltrates. Patient was searched in terms of new pneumonia or pleural edema, pulmonary thromboemboli, but all markers of these diseases were negative. But patient could not wean. Clinicians concluded APT secondary to patchy infiltrations in chest $\mathrm{x}$-ray, respiratory failure without any other reasons and high dose amiodarone medication and thorax computed tomography was performed. Bilateral ground glass opacities, significant parahiler opacities, bronchovascular irregularities, pleural and paranchimal fibrosis, small pleural effusions were detected (Figure 1). All these clinical and radiologic findings inclined clinicians to the APT. After the diagnosis, amiodarone was stopped and $50 \mathrm{mg} /$ day methylprednisolone was started. Patient's respiratory functions started to improve 5 days after the steroid therapy and patient weaned at the 9th day of the APT diagnosis. After weaning, improvement of the patient got faster. She mobilized better, oral intake increased, did not need supportive oxygen therapy and she was discharged from critical care to the ward at the 3rd day of the extubation.

\section{Discussion}

The main indication of amiodarone is suppression of ventricular arrhythmias. Additionally amiodarone can maintain sinus rhythm in patients with atrail arrhythmias $^{3,4}$. So it is a world wide used antiarrhythmic drug with its toxic side effects. Amiodarone is an iodine containing pruduct. In addition, inhibition of thyroxine deiodination to triiodothyroxine may contribute to its antiarrhythmic efficacy. An important property of amiodarone is its high lipid solubility ${ }^{1}$. These properties cause the accumulation of the drug to the tissues like
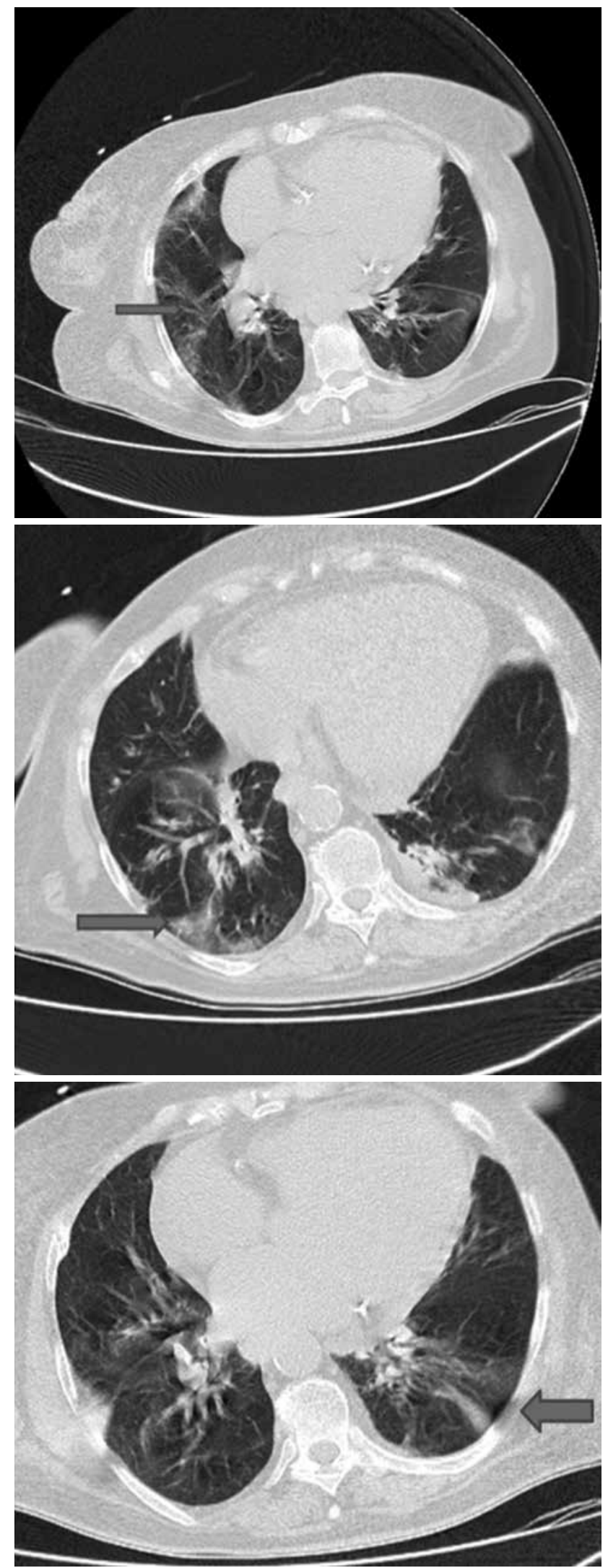

Figure 1. Bilateral ground glass opacities, significant parahiler opacities, bronchovascular irregularities, preural and paranchimal fibrosis, small pleural effusions were seen in thorax CT of the patient. 
fat, liver, spleen and lungs. The most serious one is pulmonary toxicity. Pulmonary toxicity risk correlates by plasma amiodarone concentration. Although toxicity may occur in any time or dose of the therapy but more than the dose of $400 \mathrm{mg} /$ day or theraphy of more than two months caused highest risks of pulmonary toxicity, a lower dose, commonly $200 \mathrm{mg}$ daily, for more than two years ${ }^{5}$. Male gender and pre-existing lung disease are potential risk factors of the toxicity. Additionally it was concluded that supplemental oxygen therapy, thoracic or non-thoracic surgery and mechanical ventilation may potentiate the toxicity ${ }^{6-8}$. Even our patient was female the supportive moderate oxygen therapy and mechanical ventilation might potentiate APT. The risk of developing amiodarone-induced pulmonary toxicity may increase with age and an abnormal chest xray or poor pulmonary reserve before treatment with amiodarone?

APT pathophysiology consist of direct cytotoxic T cell damage or indirect immunologic damage. ${ }^{9}$ Secondary to these mechanisms, finding cytotoxic T cells with bronchoalveolar lavage (BAL) is an one of diagnosis method. Accumulated concentrations of amiodarone derivative in specific lung compartments, such as the type II pneumocyte, further exaggerate this effect ${ }^{10}$.

The most common clinical manifestation is interstitial pneumonitis with a subacute onset ${ }^{1}$. Shortness of breath, nonproductive cough, malaise, chest pain are the common clinical presentations. ${ }^{6}$ But these findings may not be clarified in an intubated critical care patient. As our case report delayed weaning process may be the only presentation. With this aspect, the patient's weaning delayed, the dose of oxygen concentration could nor decreased and newer patchy infiltrates occured in chest $x$-ray. And the other reasons of this presentation like infectious pneumonia etc were excluded with BAL culture and other infection markers. Especially clinicians must be suspicious of APT in terms of respiratory impairments whether a critical care patient received high doses of amiodarone (our patient received $600 \mathrm{mg}$ per day) with respiratory supportive therapy.

There are no symptoms for the diagnosis of APT. New infiltrates on chest $\mathrm{x}$-ray, reduced diffusion capacity in the DLCO, restrictive or mixt type pulmonary function test results, evidence of the immune response with BAL are the diagnostic methods of APT. Interstitial, alveolar or mixt infiltrates, ground glass opacities, pleural thickening, pulmonary fibrosis are the signs of the $\mathrm{APT}^{10,11}$. In our case, bilateral ground glass opacifications, pleuroparanchimal fibrosis were detected as mentioned in previous literature.
After APT diagnosis, cessation of the drug and systemic corticosteroid therapy were recommended. It must known that amiodarone has long elimination half life and the clinical improvements may be delayed. Recurrences have been described up to 8 months after amiodarone withdrawal. Amiodarone induced fibrosis is irreversible and respondent to treatment with corticosteroid drugs ${ }^{11}$. In our patient significant clinical improvements were recorded on the 10th day of the drug cessation. Prednisone therapy is recommended in doses of $40-60 \mathrm{mg} /$ day orally ${ }^{1}$. We used $50 \mathrm{mg} /$ day methylprednisolone after the diagnosis and patients may weaned secondary to pulmonary resolution.

The prognosis of APT is usually positive. Mortality in amiodarone pneumonitis ranges between $21 \%$ and $33 \%$ of patients who are treated in hospital ${ }^{11}$.

There are numerous reports about APT but less of them from critical care. Intensive care givers must be aware of APT because being intubated and mechanically ventilated and other frequent critical care disorders like pneumonia, pulmonary thromboemboli may mask the diagnosis. It was known that prompt diagnosis, early cessation of amiodarone and steroids increase the survival rate as happens in our case.

\section{References}

1. Wolkove N, Baltzan M. Amiodarone pulmonary toxicity. Can Respir J 2009;16(2):43-8.

2. Behnia M. Association of alveolar hemorrhage with amiodarone: Role of bronchoscopy. Tanaffos 2008;7(2):75-8.

3. Vassallo P, Trohman RG. Prescribing amiodarone. JAMA 2007;298:1312-22.

4. Primeau R, Agha A, Giorgi C, et al. Long term efficacy and toxicity of amiodarone in the treatment of refractory cardiac arrhythmias. Can J Cardiol 1989;5:98-104.

5. Rotmensch HH, Belhassen B, Swanson BN et al. Steady-state serum amiodarone concentrations: Relationship with antiarrhythmic efficacy and toxicity. Ann Intern Med 1984;101:462-9.

6. Camus P, Martin WJ, Rosenow EC. Amiodarone pulmonary toxicity. Clin Chest Med 2004;25:65-75.

7. Greenspon AJ, Kidwell GA, Hurley W et al. Amiodaronerelated post-operative adult respiratory distress syndrome. Circulation 1991;84:407-15.

8. Ashrafian H, Davey P. Is Amiodarone an underrecognized cause of acute respiratory failure in the ICU. Chest 2001;120:275-82.

9. Jessurum GA, Crijns HJG. Amiodarone pulmonary toxicity. BMJ 1997;314:619-20.

10. Kuhlman JE, Teigen $\mathrm{C}$, Ren $\mathrm{H}$ et al. Amiodarone pulmonary toxicity: CT findings in symptomatic patients. Radiol 1990;177:121-5.

11. Schwaiblmair M, Berghaus T, Haeckel $T$ et al. Amiodaroneinduced pulmonary toxicity: an under-recognized and severe adverse effect? Clin Res Cardiol 2010;99:693-700. 